\title{
POSITIFISASI HUKUM ISLAM DAN FORMALISASI SYARI'AH DITINJAU DARI TEORI OTORITARIANISME KHALED ABOU EL-FADL
}

\author{
Labib Muttaqin \\ (Fakultas Syariah UIN Maulana Malik Ibrahim Malang Jl. Gajayana No, 50 \\ Malang, Email: labib_osh@yahoo.com)
}

\begin{abstract}
Abstrak:
Salah satu agenda reformasi di Indonesia adalah mewujudkan demokratisasi yang lebik, konsekwensinya kebebasan dan keterbukaan harus dibuka seluas-luasnya baik dalam bidang politik, hukum, ekonomi, budaya, dan lain-lain. Pada era ini telah menciptakan suatu kondisi yang mendukung bangkitnya kembali gerakan politik Islam di Indonesia, salah satu gerakanya adalah usaha positifisasi hukum Islam. Gerakan tersebut diasumsikan sebagai gerakan yang kontra produktif, karena positifisasi hukum Islam hanya akan terjebak dalam bingkai otoritarianisme sehingga dikhawatirkan akan menutup pintu ijtihad. Menurut Khaled Abou ElFadl, hukum Islam bukanlah hukum Tuhan itu sendiri. Hukum Islam hanyalah hasil dari proses interpretasi manusia akan hukum Tuhan. Oleh karena itu, hukum Islam tidak boleh berwatak otoriter. Dalam konteks Indonesia, praktik-praktik otoritarianisme berbasis hukum Islam kerapkali dilakukan baik oleh pemerintah maupun kelompok masyarakat tertentu, yaitu dengan menjadikan hukum Islam sebagai hukum positif. Hal ini berakibat terwujudnya hukum Islam yang kaku, mengikat, absolut, dan otoriter. Dengan demikian, terbangunlah suatu asumsi bahwa tindakan positifisasi hukum Islam hanya akan terjatuh kepada tindakan otoritarianisme.
\end{abstract}

Kata-kata Kunci:

Positifisasi Hukum Islam, Formalisasi Syari'ah, Otoritarianisme, Abou Khaled El-Fadl

Abstract:
One of the reform agenda in Indonesia is to achieve a better
democratization, consequently, freedom, and openness must be
opened wide as possible both in the fields of politics, law, economics,
culture, etc. In this era has created a condition that supports the
revival of Islamic political movements in Indonesia. One of the

al-Ihkâm Vol.11 No.1 Juni 2016

DOI: http://dx.doi.org/10.19105/al-ihkam.v11i1.859 
movements is an attempt positivization of Islamic law. The movement is assumed as the movement of the counter-productive, because positivization of Islamic law will only be stuck in the frame of authoritarianism, so feared would close the door of ijtihad. According to Khaled Abou El-Fadl, Islamic law is not the law of God itself. Islamic law is merely the result of the process of human interpretation of the law of God. Therefore, Islamic law should not be authoritarian character. In the Indonesian context, the practices of Islamic law based authoritarianism is often done either by the government or certain groups of people, namely by making Islamic law as a positive law, this has resulted in the establishment of strict Islamic law, binding, absolute, and authoritarian. Thus awakened an action positivization assumption that Islamic law would only fall to the action of authoritarianism.

\section{Key Words:}

Positivization of Islamic Law, Formalizatiton of Sharia, Authoritarianism, Abou Khaled El-Fadl

\section{Pendahuluan}

Pasal 1 ayat (3) UUD Negara Republik Indonesia 1945 di nyatakan bahwa Negara Indonesia adalah Negara hukum. Dalam konsep Negara Hukum ${ }^{1}$ itu, diidealkan bahwa yang harus dijadikan panglima dalam dinamika kehidupan kenegaraan adalah hukum, bukan politik ataupun ekonomi. Karena itu, jargon yang biasa digunakan dalam bahasa Inggris untuk menyebut prinsip Negara Hukum adalah 'the rule of law, not of man'. Eksistensi hukum Islam memberikan warna tersendiri bagi sistem hukum yang selama ini berkembang di Indonesia, bahkan dalam sistem hukum di Indonesia, hukum Islam merupakan salah satu bagian dari sistem hukum yang berlaku di Indonesia selain Hukum Positif dan Hukum adat.

\footnotetext{
${ }_{1}^{1}$ M.r. L.J. van Apeldoorn mengatakan "bahwa tidak mungkin memberikan suatu definisi tentang apakah itu hukum itu", namun dari beberapa perumusan tentang hukum yang diberikan oleh para sarjana hukum dapatlah diambil kesimpulan bahwa hukum meliputi beberapa unsur yeitu; (1) Peraturan mengenai tingkah laku manusia dalam pergaulan masyarakat (2) Peraturan (hukum) itu diadakan oleh badan-badan resmi yang berwajib (3) Peraturan itu bersifat memaksa dan (4) Apabila peraturan tersebut dilanggar maka pihak yang melanggar mendapatkan sanksi. C.ST. Kansil, Pengantar Ilmu Hukum dan Tata Hukum Indonesia (Jakarta: Balai Pustaka, 2002), 4.
} 
Era Reformasi yang sering disebut sebagai era keterbukaan dan kebebasan politik telah menciptakan sebuah kondisi yang mendukung kebangkitan kembali politik Islam dan ketumbuhan gagasan-gagasan tentang positifisasi atau formalisasi syariat Islam di Indonesia. Bukti yang menunjukkan terjadinya kebangkitan politik Islam dan tumbuhnya kembali gagasan-gagasan tentang formalisasi syariat Islam di Indonesia pada era Reformasi setidaknya dapat dilihat dari empat indikator, yaitu: (1) munculnya ormas Islam pendukung gerakan formalisasi syariat Islam; (2) berdirinya partaipartai Islam; (3) adanya tuntutan pemberlakuan Piaga Jakarta dalam konstitusi; (4) munculnya gerakan penegakan syariat Islam di Daerah. $^{2}$

Usaha-usaha memposisikan hukum Islam sebagai hukum posotif atau juga memformalisasikan hukum Islam (biasa disebut formalisasi syariah) memiliki konsekwensi yang besar dalam bingkai berbangsa dan bernegara bagi masyarakat Indonesia, hal tersebut akan mengakibatkan masyarakat Indonesia tidak memiliki pilihan lain kecuali melaksankan hukum Islam yang telah tetapkan menjadi hukum positif $^{3}$ di Indonesia, padahal hukum tersebut hanyalah hasil interpretasi manusia belaka yang bisa jadi hasil interpretasi tersebut termasuk dalam perkara khilâfiyah. Secara harfiah, khilâfiyah berarti perbedaan, perselisihan, dan pertentangan. ${ }^{4}$ Khilâfiyah berarti masalah-masalah fiqh yang diperselisihkan, dipertentangkan, diperdebatkan status hukumnya di kalangan ulama (ahli hukum Islam) akibat dari pemahaman dan penafsiran mereka terhadap nash yang berbeda. Apabila suatu kasus hukum yang berstatus khilâfiyah dipaksakan baik oleh individu maupun institusi kepada masyarakat

2Said Agil Husin Al-Munawar, "Kata Pengantar: Islam dalam Konteks KeIndonesiaan: Beberapa Soal yang Segera Dirumuskan”, dalam Masykuri Abdillah, et.al, Formalisasi Syariat Islam di Indonesia: Sebuah Pergulatan yang Tak Pernah Tuntas (Jakarta: Renaisan, 2005), xiv.

${ }^{3}$ Hukum positif atau ius constitutum adalah kumpulan asas dan kaidah hukum tertulis yang pada saat ini sedang berlaku dan mengikat secara umum atau khusus dan ditegakkan oleh atau melalui pemerintah atau pengadilan dalam negara Indonesia. Bernard L. Tanya, et.al, Teori Hukum: Strategi tertib Manusia Lintas Ruang dan Generasi (Yogyakarta: Genta Publishing, 2010), 4.

${ }^{4}$ AW. Munawwir, Kamus al-Munawwir Arab-Indonesia Terlengkap (Surabaya: Penerbit Pustaka Progresif), 363. 
yang mungkin memiliki interpretasi yang berbeda mengenai hukum tersebut, maka pemaksaan tersebut adalah tindakan otoritarianisme.

Khaled Abou El-Fadl memiliki beberpa definisi tentang otoritarianisme, Pertama, tindakan mengunci teks dan mengurung kehendak tuhan atau kehendak teks, dalam sebuah penetapan makna, dan kemudian menyajikan penetapan tersebut sebagai sesuatu yang pasti, absolute, dan menetukan. Kedua, otoritarianisme merupakan tindakan yang melampaui otoritas atau kekuasaan yang dimandatkan sedemikian rupa sehingga menyelewengkan atau mengambil alih kekuasaan dari pemberi mandat. ${ }^{5}$ Ketiga, otoritarianisme merupakan tindakan dari orang-orang yang menggunakan simbolisme dari komunitas interpretasi hukum tertentu untuk mendukung argumentasi mereka. Keempat, otoritarianisme merupakan pengabaian terhadap realitas ontologism Tuhan dan pengambilalihan kehendak Tuhan oleh wakil Tuhan sehingga wakil tersebut secara efektif kemudian mengacu kepada dirinya sendiri.

Lebih lanjut El-Fadl menjelaskan, proses interpretasi yang berorientasi kearah sikap otoritarianisme ditandai dengan munculnya penetapan yang bersifat tetap dan tidak bisa berubah dari hasil suatu interpretasi. ${ }^{6}$ Dengan kata lain otoritarianisme adalah tindakan merasa paling benar dalam menginterpretasikan ayat al-Qur'an dan memaksakan hasil interpretasinya untuk dilaksanakan oleh orang lain tanpa memperdulikan adanya pendapat yang berbeda dengan dirinya.

Dalam menggapi hukum Islam yang dijadikan sebagai hukum positif, Abou El-Fadl menanggapinya dengan negatif:

Bahkan pada kasus yang berkaitan dengan sebuah putusan hakim, kita boleh terus percaya dan menyatakan bahwa hukum positif telah salah memahami teks ilahi. Bahkan seorang hakim sekalipun harus mengakui kenyataan bahwa ia hanya mewakili sebuah pendapat tentang hukum Tuhan, dan keputusanya bukunlah hukum Tuhan itu sendiri. ${ }^{7}$

Definisi El-Fadl tentang otoritarianisme memberikan tinjauan kritis terhadap gerakan formalisasi syariah atau positifisasi hukum

\footnotetext{
${ }^{5}$ Khaled Abou El-Fadl, Atas Nama Tuhan, Dari Fikih Otoriter ke Fikih Otoritatif, terj. R. Cecep Lukman Yasin (Jakarta: Serambi, 2004), hlm. 138.

${ }^{6}$ Ibid., hlm. 206.

7 Ibid., hlm. 220.
} 
Islam khususnya di Indonesia yang notabene bukanlah Negara agama. Uraian di atas memunculkan pertanyaan seperti; relevankan gerakan formalisasi syariah baik didunia pada umumnya maupun di Indonesia pada khususnya? Bagaimanakah seharusnya posisi hukum Islam dalam bingkai Negara-bangsa (nation-state) seperti Indonesia?

\section{Biografi Khaled Abou El-Fadl}

Nama lengkap El-Fadl adalah Khaled Medhiat Abou El- Fadl. Ia dilahirkan pada 1963 di daerah Kuwait. Pada masa muda, Abou ElFadl dikenal sebagai anak yang cerdas. Pada usia 12 tahun, ia sudah hafal al-Qur`an dan mengikuti kelas Syariah di masjid lokal di daerahnya. Ia juga rajin mempelajari semua koleksi buku orang tuanya yang berprofesi sebagai pengacara. ${ }^{8}$

Negara Kuwait pada masa itu memiliki pemerintahan yang represif dan otoriter. Mereka menyensor bahan-bahan bacaan masyarakatnya. Sehingga mengakibatkan, El-Fadl yang tumbuh di lingkungan yang bersifat puritan-tradisional, mendambakan terealisasinya kebangkitan peradaban Islam. El-Fadl menginginkan sebuah peradaban sebagaimana pengalaman kejayaan Nabi di Madinah.

Setelah memperdalam ilmunya, El-Fadl meyakini kekayaan tradisi intelektual Islam. Dari keyakinan tersebut, memberikan dia motivasi positif untuk mengkaji lebih dalam kekayaan tradisi intelektual Islam dengan melakukan studi di Timur Tengah dan Universitas-Universitas ternama di Amerika. Sebelum menetap di Barat, El-Fadl sempat menimba ilmu di Mesir, di sana ia mulai merasakan adanya iklim akademis yang kondusif dan keterbukaan intelektual, berbeda dengan di Kuwait. Menurutnya, sistem kekuasaan yang represif dan otoriter, tidak akan pernah melahirkan kemajuan berpikir dan pencerahan intelektual terhadap masyarakatnya. Kebebasaan intelektual sebagaimana ia peroleh di Mesir, semakin dirasakan ketika ia hijrah ke Amerika. ${ }^{9}$

8 Abid Rohmanu, Konsepsi Jihad Aboe El-Fadl, (Disertasi Pasca Sarjana IAIN Sunan Ampel Surabaya, 2006), 26.

9 Khaled M. Abou El-Fadl, Melawan Tantara Tuhan: Yang Berwenang dan Sewenangwenang dalam Islam, terj. Kurniawan Abdullah, (Jakarta: Serambi, 2003), 18. 
Prestasi akademis El-Fadl di Amerika dimulai dari Yale University pada 1982 dalam bidang ilmu politik, dengan kemampuan bahasa Inggris yang masih sangat lemah. Akan tetapi, empat tahun kemudian ia bisa meraih magna cum laude (lulus dengan peringkat sangat memuaskan pada level Universitas dan diploma) dan memperoleh penghargaan sebagai mahasiswa berbakat. Pada 1986, ia melanjutkan studi hukum ke University of Pennsylvania Law School untuk memperoleh gelar Jurist Doctor (J.D.) hingga 1989. Setelah itu, El-Fadl melanjutkan studi ke Princeton University, dan pada 1999 ia bisa menyelesaikan program doktornya dalam bidang pemikiran hukum Islam dengan gelar Doctor of Philosophy. Di Princeton ini, ElFadl mendapatkan nilai kumulatif yang cukup memuaskan dengan disertasi terbaiknya "Rebellion and Violence in Islamic Law". Pada saat yang bersamaan, El-Fadl menempuh studi hukum di UCLA (University of California Los Angeles). ${ }^{10}$

Pada 1989, Ia bekerja di Pengadilan Tinggi Arizona (Arizona Supreme Court) menangani persoalan hukum keimigrasian dan komersial (Commercial and Immigration Law). Sejak saat itu, ia diakui menjadi warga negara Amerika. El-Fadl juga pernah mengajar hukum Islam di University of Texas. Pada saat itulah, Irene Bierman, Kepala Pusat Kajian Wilayah Timur Tengah UCLA (UCLA's Center for Near Eastern Studies) melihat kemampuannya sehingga pada 1998, Irene Bierman mengusulkannya menjadi pengurus baru dalam bidang hukum Islam. Aktifitasnya di UCLA mengantarkannya pada puncak karir, menjadi profesor hukum Islam di UCLA (University of California Los Angeles) School of Law.

Pengetahuan yang luas dan kontribusi yang ia sumbangkan ke dunia menjadikan dirinya mendapatkan banyak penghargaan dan apresiasi dari masyarakat antara lain : dianugerahi University of Oslo Human Rights Award, pada 2007 dia dianugerahi Lisler Eitenger Prize serta tahun 2005 mendapatkan anugerah Carnegei Scholar in Islamic law. El-Fadl bahkan pernah ditugaskan oleh Presiden George Washington Bush untuk menjadi pemantau dalam komisi untuk kebebasan beragama internasional (U.S. Commission for International Religious Freedom), dia juga bertindak sebagai anggota DewanDirektur pemantau hak azasi manusia (Human Rights Watch), anggota dewan

10Rohmanu, Konsepsi Jihad, 27. 
penasihat middle east watch (bagian dari human Right Watch), serta secara teratur bekerja dengan organisasi Hak Azasi Manusia seperti: Amnesty Internasional and the Lawres Committe for Human Rights sebagai ahli dalam pemecahan berbagai kasus tentang HAM, terorisme, politik suaka, hukum komersial dan internasional. Tahun 2005, ia termasuk sebagai salah satu dari 500 pengacara terbaik di Amerika Serikat. ${ }^{11}$

Selain prestasi yang ia miliki, El-Fadl juga merupakan sosok penulis yang sangat produktif sehingga ditemukan banyak karya baik berupa artikel ataupun buku beliau, antara lain: Islam and the Chelllengge of Democracy (PrincetonUniversity Press, 2004), The Place of Tolerance in Islam (Cambridge University, 2001), Rebellion dan Violence in Islamic Law ( Cambridge University, 2001), Speaking in GodsName: Islamic Law, Authority, dan Woman (Oneworld Publication, 2001), And Godknows the Soldiers: The Authoritative and Authoritarian in Islamic Discourse (2001), Conference of The Books: The Search for the Beauty in Islam (2001). ${ }^{12}$

\section{Teori Otoritarianisme Abou El-Fadl}

Dalam tulisan ini, otoritarianisme yang dimaksud adalah teori yang digagas oleh Abou El-Fadl. Sebelum mengkaji lebih lanjut teori dari El-Fadl mengenai otoritarianisme, ada baiknya jika terlebih dahulu akan dijelaskan tentang pemahaman terhadap istilah otoritas. Hannah Arendt mendefinisikan otoritas sebagai sebuah kekuatan yang membuat orang tunduk tanpa harus dibujuk. Sedangkan Fredman mendefinisikan otoritas sebagai kemampuan untuk mempengaruhi orang lain untuk mengikuti bentuk perbuatan tertentu dengan memperlihatkan manfaat dari perbuatan tersebut. ${ }^{13}$

Abou El-Fadl membedakan jenis otoritas yang bersifat koersif dengan otoritas yang bersifat persuasif. Otoritas yang bersifat koersif merupakan kemampuan untuk mengarahkan perilaku orang lain dengan cara membujuk, mengambil keuntungan, mengancam, atau menghukum, sehingga orang yang berakal sehat akan berkesimpulan bahwa untuk tujuan praktis mereka tidak punya pilihan lain kecuali

\footnotetext{
11Wikipedia, Khaled Abou El-Fadl: https://en.wikipedia.org/wiki/Khaled_Abou_El_Fadl. diakses tanggal 14 Juli 2015. 12El-Fadl, Melawan Tantara Tuhan, 18.

${ }^{13}$ El-Fadl, Atas Nama Tuhan, 38.
} 
harus menurutinya. Sedangkan otoritas persuasif merupakan kemampuan untuk mengarahkan keyakinan atau perilaku seseorang atas dasar keprcayaan. ${ }^{14}$

Meminjam terminologi Richard Friedman, Abou El-Fadl membedakan antara "memangku otoritas" (being in authority; berada di dalam kekuasaan) dan "memegang otoritas (being anauthority; keberadaan kekuasaan). Menurut Friedman sebagaimana dikatakan Abou El-Fadl, "memangku otoritas" diartikan suatu otoritas didapatkan dengan jabatan struktural dan cenderung memaksa kepada orang lain untuk menerima otoritas tersebut. Dalam kasus ini tidak dikenal adanya "ketundukan atas keputusan pribadi", karena seseorang bisa saja berbeda pendapat dengan yang memangku otoritas, namun tidak memiliki pilihan lain kecuali menaatinya. Sedangkan "pemegang otoritas" adalah suatu otoritas yang didapatkan tanpa jabatan struktural dan paksaan, melinkan karena kapabilitas dan akseptabilitas seseorang yang akhirnya memunculkan kesadaran orang lain untuk menerimanya. ${ }^{15}$

Lebih dari itu, Abou El-Fadl memiliki beberpa definisi tentang otoritarianisme. Pertama, tindakan mengunci teks dan mengurung kehendak tuhan atau kehendak teks, dalam sebuah penetapan makna, dan kemudian menyajikan penetapan tersebut sebagai sesuatu yang pasti, absolute, dan menetukan. Kedua, otoritarianisme merupakan tindakan yang melampaui otoritas atau kekuasaan yang dimandatkan sedemikian rupa sehingga menyelewengkan atau mengambil alih kekuasaan dari pemberi mandat. ${ }^{16}$

Ketiga, otoritarianisme merupakan tindakan dari orang-orang yang menggunakan simbolisme dari komunitas interpretasi hukum tertentu untuk mendukung argumentasi mereka. Keempat, otoritarianisme merupakan pengabaian terhadap realitas ontologism

14 Ibid., 37.

15Menaggapi konsep otoritas Richard Friedman, Abou El Fadl Keberatan terhadap terminologi Friedman karena terminologi tersebut bersifat membatasi. Menurut ElFadl terminologi "pemangku otoritas" tidak bisa digunakan secara tepat, sebab jabatan resmi dan kekuasaan yang dimiliki seseorang yang memangku otoritas tidak bisa diketahui secara jelas.Lebih spesifik lagi, dalam konteks hukum Islam, menyejajarkan otoritas dengan praktik taklid adalah sangat tidak tepat. El-Fadl, Atas Nama Tuhan, 40-42.

16Ibid.,138. 
Tuhan dan pengambilalihan kehendak Tuhan oleh wakil Tuhan sehingga wakil tersebut secara efektif kemudian mengacu kepada dirinya sendiri. Dengan kata lain otoritarianisme adalah tindakan merasa paling benar dalam menginterpretasikan ayat al-Qur'an dan memaksakan hasil interpretasinya untuk dilaksanakan oleh orang lain tanpa memperdulikan adanya pendapat yang berbeda dengan dirinya.

El-Fadl mencontohkan sikap otoritarianisme tersebut dipraktekan oleh salah satu lembaga fatwa di Arab Saudi yaitu CRLO. Sebelum membahas lebih jauh tentang CRLO, terlebih dahulu akan membahas lembaga hukum di Arab Saudi. Ada dua institusi yang mempunyai kewenangan dalam menyelesaikan persolan hukum di Arab Saudi, yaitu Mahkamah Syar'iyah dan Lembaga Fatwa. Kedua lembaga ini memiliki kewenangan yang berbeda. Mahkamah Syar'iyah mempunyai kewenangan absolute dan relatif. Mahkamah Syar'iyah merupakan lembaga yudikaitf yang bertugas memeriksa perkara pidana (jinâyah), perkara perdata (mu'âmalah), dan wilayah yurisdiksinya terbatas berdasarkan kompetensi relatifnya. ${ }^{17}$

Sedangkan lembaga fatwa berfungsi memberikan keputusan hukum atas suatu persoalan yang menyangkut dengan kemaslahatan umum, baik menyangkut dengan masalah hak kewarganegaraan maupun persoalan politik baik dalam negeri maupun luar negeri. Keputusan lembaga fatwa ini bersifat mengikat bagi seluruh warga negara Arab Saudi, ${ }^{18}$ dan CRLO merupakan lembaga fatwa yang ada di Arab Saudi.

CRLO (Council for Saintific Research and Legal Opinion atau alLajnah ad-Daimah li al-Buhts al-'Ilmiyyah wa al-Ifta') merupakan sebuah lembaga resmi di Saudi Arbia yang mempunyai otoritas untuk mengeluarkan fatwa-fatwa keagamaan yang dianggap oleh Abou ElFadl terjebak pada sikap otoritarianisme, seperti fatwa pelarangan perempuan mengunjungi makam suami, perempuan mengeraskan suara dalam berdo'a, perempuan mengendarai dan mengemudikan mobil sendiri, dan perempuan harus didampingi pria mahramnya. ${ }^{19}$

17 Munawir Sjadzali, Islam dan Tata Negara (Ajaran, Sejarah dan Pemikiran (Jakarta: UI Press, 1993), 34.

18 Ibid.

${ }^{19}$ Fatwa-fatwa tersebut dianggap oleh Abou el-Fadl, sebagai tindakan merendahkan untuk tidak menyebutnya menindas - wanita yang tidak dapat ditoleransi pada era 
Menurut El-Fadl, fatwa-fatwa tersebut hanya akan menggambarkan citra Islam sebagai ajaran yang eksklusif, sektarian, primordial, intoleran, dan anti perubahan. Menurutnya, metode penetapan hukum oleh institusi fatwa tersebut didasarkan pada selektifitas teks otoritatif dan mengubahnya menjadi teks yang otoriter. Proses ini terjadi karena mendekati teks dan menyatakan suatu ketetapan makna tanpa memberi ruang bagi pamaknaan lain. Dengan begitu, institusi fatwa tersebut telah memposisikan dirinya sama dengan teks itu sendiri, dan bukanhanya berusaha mengkonstruksi makna teks, tetapi juga telah mengkonstruksi teksitu sendiri. Tidak sampai di situ saja, institusi fatwa seperti CRLO tersebut bahkan kemudian mengidentifikasi diri sebagai "tentara" Tuhan dengan mengklaim penafsirannya sebagai yang paling otoritatif, dan harus diikuti oleh pihak lain. Dengan begitu, kedua institusi fatwa tersebut telah "memerkosa" teks. ${ }^{20}$

Abou El-Fadl juga mencontohkan fenomena mutakhir dari praktik otoritarianisme tersebut yang terjadi pada gerakan puritanisme Islam Wahabi. Gerakan yang bermarkas di Saudi Arabia ini mendapat dukungan pemerintah sebagai kekuatan politik, yang tendensinya untuk menutup gerak dinamika teks, sehingga hanya tersisa kebenaran tunggal. Geneologi fundamentalisme dari gerakan teologi dan madzhab-madzhab fikih yang bersikap anti toleransi dan pluralisme bisa dilacak dari tendensi ini. Mereka, baik secara individu maupun kelompok telah merasa memonopoli kebenaran, sementara pendapat orang lain tidak mungkin diakomodasi. Mereka berposisi sebagai pemegang kebenaran dan karenanya berhak untuk melakukan value judgment atas kelompok lain sebagai "tidak Islam", sesat, kafir, dan seterusnya. ${ }^{21}$

Otoritarianisme ini mereka lakukan dengan tanpa memerdulikan aturan metodologi pengambilan keputusan hukum

sekarang ini. Fatwa-fatwa ini dikatakan berlindung di bawah teks (nash) yang mengklaim bahwa itulah yang sebenarnya "dikehendaki oleh Tuhan" Amin Abdullah, "Pendekatan Hermeneutik dalam Studi Fatwa-fatwa Keagamaan", dalam kata pengantar El-Fadl, Atas Nama Tuhan, ix.

20Ibid., 238-246.

${ }^{21}$ Mun'im A. Sirry, “Islam, Teks Terbuka dan Pluralisme”, Jurnal Perspektif Progresif, Vol. 1, No. 1 (Juli-Agustus, 2005), 30. 
yang telah dilakukan oleh ulama-ulama klasik. ${ }^{22}$ Para ulama tersebut dengan mudah mengeluarkan fatwa-fatwa atau value judgement pada setiap persoalanyang dihadapi tanpa memperdulikan nilai-nilai universal. Fatwa-fatwa yang disampaikan bersifat monolitik-linear. Ulama tersebut dengan ringan mengatakan bahwa seseorang tidak perlu berpikir tentang hal-hal seperti itu, katakan saja terkait problem gender atau fatwa-fatwa keagamaan Islam tentang perempuan.

\section{Positifisasi Hukum Islam di Indonesia}

Islam sebagai agama mayoritas penduduk Indonesia, di dalamnya mengandung hukum yang mengatur hubungan manusia dengan manusia lain dalam kehidupan bermasyarakat. Karenanya, berbekal realitas tersebut terdapat berbagai usaha dari berbagai golongan untuk menjadikan hukum Islam sebagai hukum nasional. Secara sederhana dapat dijelaskan bahwa hukum nasional adalah hukum positif yang berlaku secara umum (secara nasional) bagi seluruh warga Negara Indonesia, di mana hukum positif yang berlaku di Indonesiadapat berasal dari hukum adat, hukum Islam dan hukum Barat (Belanda), dan hukum internasional. ${ }^{23}$

Sebelum membahas lebih jauh mengenai eksistensi hukum Islam di dalam hukum nasional Indonesia, telebih dahulu akan dibahas mengenai positifisasi hukum, terutama kaitanya dengan positifisme hukum sebagai bagian dari filsafat hukum, sehingga tidak mucul pengertian yang rancu dari keduanya. Kata positifisasi bukanlah derivasi dari positifisme dalam madzhab filsafat hukum, tetapi antara keduanya memiliki relevansi. Jika positifisme hanya menerima hukum apa adanya, yaitu berupa peraturan-peraturan yang dibuat dan diakui oleh negara, maka positifisasi adalah upaya

${ }^{22}$ Menurut El-Fadl epistemologi dan premis-premis normatif yang mengarahkan perkembangan dan pengembangan tradisi hukum Islam klasik, kini sudah tidak ada lagi. Tradisi hukum Islam klasik merupakan tradisi yang menjunjung premis-premis pembentukan hukum yang anti otoritarianisme, premis-premis serupa itu tidak lagi diberlakukan dalam tradisi hukum Islam dewasa ini. El-Fadl, Atas Nama Tuhan, 2.

${ }^{23}$ Definisi hukum banyak sekali jumlahnya.Definisi hukum yang berlaku di antara para sarjana hukum sebenarnya menggambarkan sistem yang digunakan dalam negaranya masing-masing, dan karena itu merupakan generalisasi dari teknik hukum yang disesuaikan dengan keadaan sosial yang konkret. Georges Gurvitch, Sosiologi Hukum, Terj. Sumantri Mertodipuro dan Moh. Radjab, (Jakarta: Penerbit Bhratara, 1988), 43. 
untuk menjadikan sebuah ketentuan menjadi hukum resmi negara. Bagi positifisme, yang disebut hukum adalah norma yang telah melewati proses positifisasi. Oleh karena itu antara positifisasi dan madzhab positifisme memiliki obyek yang sama, yakni norma yang telah menjadi norma hukum. ${ }^{24}$

Apabila madzhab positifisme menganggap bahwa apa yang benar adalah yang nyata, pasti dan jelas maka positifisme hukum beranggapan bahwa hukum positif adalah yang nyata, pasti dan benar. Bagi positifisme, positifisasi hukuma dalah mutlak. Positifisasi adalah proses transformatif dari hukum dalam wujudnya yang metafisik sebagai ide ke hukum dalam bentuknya yang lebih konkrit dan tersimak ada secara indrawi. Lewat proses positifisasi, hukum yang semula berupa norma keadilan, moral, dan etika yang tidak memiliki kekuatan memaksa dan mengikat menjadi hukum menjadi hukum positif yang tertulis yang harus memaksa seseorang untuk mentaatinya. ${ }^{25}$

Aspirasi tentang positifisasi hukum Islam dalam konteks hukum nasional sangat terkait dengan pandangan atau orientasi seseorang atau suatu kelompok tentang posisi Islam dalam konteks kehidupan bernegara.Orientasi Islam ini dapat diklasifikasikan menjadi tiga kelompok. Pertama, adalah orientasi yang berupaya memperjuangkan implementasi ajaran secara komprehensif (kaffah), baik bidang aqidah, syari'ah maupun etika moral. Kedua, adalah orientasi yang hanya berupaya memperjuangkan implementasi akidah dan etika moral Islam. Ketiga, orientasi yang berupaya memperjuangkan sedapat mungkin implementasi syari'ah disamping aqidah dan etika moral atau minimal prinsip-prinsipnya yang terintegrasi ke dalam sistem nasional. Orientasi pertama menjadikan Islam sebagai ideologis, kedua menjadikan Islam sebagai sumber etika moral, dan ketiga menjadikan Islam sebagai sub-ideologi. ${ }^{26}$

\footnotetext{
${ }^{24}$ Achmad Ali, Menguak Teori Hukum (Legal Theory) dan Teori Peradilan (Judicialprudence) Termasuk Interpretasi Undang-Undang/Legisprudence, (Jakarta: Kencana, 2009), 61.

${ }^{25}$ Widodo Dwi Putro, Kritik Terhadap Paradigma Positivisme Hukum, (Yogyakarta: Genta Publising, 2011), 54.

26Masykuri Abdillah, et.al, Formalisasi Syari'at Islam di Indonesia Sebuah Pergulatan Yang Tak Pernah Tuntas, (Jakarta: Renaisan. 2005), 319-320.
} 
Orientasi pertama ini didukung oleh mereka yang masih tetap concerned terhadap orientasi Islam sebagai ideologi yang manifestasinya berbentuk pelaksanaan syari'ah Islam secara formal sebagai hukum positif. Orientasi ini mendukung pendekatan structural dalam sosialisasi dan institusionalisasi ajaran Islam. orientasi ini sebenarnya sudah dimiliki oleh para tokoh Islam menjelang dan pada masa-masa awal kemerdekaan Indonesia, kemudian sejalan dengan era globalisasi, orientasi ini banyak dipengaruhi ide-ide ikhwanul muslimin yang berdiri di Mesir tahun 1928 dan kini sudah berkembang di sejumlah negara Timur Tengah. ${ }^{27}$

Di Indonesia fase kodifikasi maupun kompilasi hukum Islam ke dalam hukum positif pada kenyataannya terjadi sejak kemerdekaan. Hal tersebut terbukti dengan lahirnya beberapa undang-undang yang mengangkat aspek hukum Islam. Masuknya hukum Islam ke dalam beberapa peraturan perundang-undangan, ada yang langsung menyebut dan menggunakan istilah hukum Islam dan berlaku khusus bagi masyarakat Islam, maupun yang berlaku umum dengan memasukkan substansi hukum Islam. ${ }^{28}$

Usaha positifisasi hukum Islam di Indonesia sudah terlihat sejak awal-awal kemerdekaan, di mana elit-elit Islam berjuang sekuat tenaga untuk memasukan satu frase dalam pembukaan UndangUndang Dasar 1945, yang mewajibkan penduduk beragama Islam untuk senantiasa menjalankan kewajiban agama mereka. Hal inilah yang dikenal dengan Piagam Jakarta yang diyakini dapat memberi dasar konstitusional bagi penerapan syariat atau hukum Islam di Indonesia.

Pasca Soekarno, tepatnya di awal masa orde baru, perdebatanva berlanjut ketika partai-partai Islam, meminta pemerintah untuk menghidupkan kembali Piagam Jakarta sebagai bagian integral dalam pembukaan Undang-undang Dasar 1945. Usaha ini kembali menemui jalan buntu karena militer tidak mengizinkan isu tersebut didiskusikan pada sidang-sidang MPR RI tahun 1966-1967.29

27Ibid., 320 .

28 Jazuni, Legislasi Hukum Islam di Indonesia, (Bandung: PT.Citra Adtya Bakti, 2005), 336.

${ }^{29}$ Burhanuddin, Syari'at Islam Pandangan Muslim Liberal, (Jakarta: The Asia Fondation, 2003), 60. 
Meskipun Piagam Jakarta yang akan memberi status konstitusional pada syariat, tidak diakomodasi oleh pemerintah Seoharto sebagai bagian dari Undang-undang Dasar 1945, beberapa aspek yang berkenaan dengan syariat telah dilegislasikan dalam sistem hukum nasional. Paling sedikit ada lima aturan hukum yang secara kuat dipengaruhi oleh syari'at, telah dilegislasikan dalam hukum positif di masa Soeharto, yaitu Undang-undang Perkawinan, Peraturan Wakaf, Peradilan Agama, Hukum yang membolehkan beroperasinya perbankan Islam, dan Kompilasi hukum Islam yang terkait dengan kodifikasi hukum keluarga dalam Islam, termasuk aturan waris. Semasa pemerintahan presiden Habibie (1998-1999), ada tambahan dua Undang-undang yang mencakup penyelenggaraan haji dan pengelolaan zakat. ${ }^{30}$

Pasca reformasi, undang-undang yang mengangkat aspek hukum Islam juga terus bermunculan, diantaranya adalah UndangUndang Nomor 18 tahun 2001 Tentang Otonomi Khusus Bagi Propinsi Nangroe Aceh Darussalam (NAD), dimana lembaga peradilan secara khusus di Propinsi Nangroe Aceh Darussalam (NAD) sebagai bagian dari sistem peradilan nasional dilakukan oleh mahkamah Syar'iyah. Undang-Undang Nomor 3 Undang-Undang Nomor 2006 Tentang Perubahan Undang Undang Nomor 7 tahun 1989 Tentang Peradilan Agama, dimana terdapat beberapa perubahan yang memperluas tentang kewenangan Pengadilan Agama dalam menyelesaikan sengketa di bidang pengelolaan zakat, serta sengketa di bidang ekonomi syariah. Selain itu juga terdapat undang-undang lain seperti Undang-Undang Nomor 38 tahun 1999 tentang Pengelolaan Zakat, Undang-Undang Nomor 41 Tahun 2004 Tentang Wakaf, Undang-Undang Nomor 13 tahun 2008 perubahan atas Undang-Undang No. 17 Tahun 1999 Tentang Penyelenggaraan Ibadah Haji, Undang-undang Nomor 21 Tahun 2008 Tentang Perbankan Syariah.

Implementasi hukum Islam kedalam hukum positif tidak hanya diberlakukan pada undang-undang saja yang notabene bersifat nasional. Positifisasi hukum Islam juga kerapkali dilakukan oleh sejumlah pemerintah daerah. Dalam semangat penegakan syariat Islam, mereka (kepala daerah) membuat peraturan-peraturan daerah

30Ibid., 61. 
terdaerah tentang syariat Islam, peraturan ini kerapkali disebut perda syariah. Pemberlakuan perda syariah terdapat diberbagai daerah seperti di Aceh, Sulawesi Selatan, Riau, Banten, Cianjur, Tasikmalaya, Indramayu, dan lain-lain. Bahkan, di Aceh syariat Islam telah secara resmi diberlakukan sebagai hukum positif.

\section{Gagasan dan Gerakan Formalisasi Syariah di Indonesia}

Selain telah dipositifkanya sebagaian hukum Islam baik oleh pemerintah pusat maupun daerah, gagasan-gagasan tentang formalisasi syariah juga banyak di lontarkan oleh berbagai kalangan. Bukti yang menunjukkan terjadinya kebangkitan politik Islam dan tumbuhnya kembali gagasan-gagasan tentang formalisasi syariat Islam di Indonesia dapat dilihat dari empat indikator yaitu;31 Pertama, munculnya ormas Islam pendukung gerakan formalisasi syariat Islam, yaitu beberapa organisasi kemasyarakatan (or-mas) Islam lengkap dengan gerakan massanya,seperti Hizbut Tahrir Indonesia (HTI), Majelis MujahidinIndonesia (MMI), Front Pembela Islam (FPI), Forum Komunikasi Ahlussunnah Waljamaah (FKASW),Laskar Jihad, dan sebagainya.Mereka pada umumnya memiliki tujuan yang sama, yakni penerapan syariat Islam sebagai hukum positifdi Indonesia.

Kedua, berdirinya partai-partai Islam, Pada era Reformasi, telah terjadi liberalisasi politik, sehingga cukup banyak partai politik yang baruberdiri tidak mencantumkanPancasila sebagai asasnya, justru yang dicantumkan sebagai asas partai adalah Islam, bahkan Partai Persatuan Pembangunan (PPP) yang pada masa Orde Baru berasaskan Pancasila, pada era Reformasi melakukan perubahan dengan mencantumkan Islam sebagai asasnya. Partai politik yang ada pada masa Reformasi mencapai 184 partai. Dari jumlah tersebut, 148partai mendaftarkan diri ke Departemen Kehakiman; dan 141diantaranya memperoleh pengesahan sebagai partai politik. Partai politik Islam yang berdiripada saat itu ada sekitar 38 partai. Dapat dilihat bahwa pada eraReformasi partai politik Islam yang berdiri cukup banyak.

Ketiga, adanya tuntutan pemberlakuan Piagam Jakarta dalam konstitusi yang menunjukan pemberlakuan syariat Islam yaitu

\footnotetext{
31Zudi Setiawan, "Dinamika Pergulatan Politik dan Pemikiran Formalisasi Syariah
} Pada Era Reformasi", Jurnal Spektrum, Vol. 5, No. 2 (Juni 2008), 79. 
memasukan tujuh frasa yang berbunyi "dengan kewajiban menjalankan syariat Islam bagi pemeluk-pemeluknya".Tuntutan ini pertama kali muncul ke permukaan pada era Reformasi dapat dilihatdari adanya usulan resmi tentang pemberlakuan kembali Piagam Jakarta yang dilakukan oleh Partai Persatuan Pembangunan (PPP)pada saat berlangsung Sidang Istimewa (SI) MPR 1998. Gagasanini kembali mengemuka ketika Badan Pekerja (BP) MPR sedang membahas amandemen terhadap UUD 1945. Setidaknya, pada tahun 2000 ada dua fraksi di MPR, yakni dari Partai Persatuan Pembangunan (PPP) dan Partai Bulan Bintang (PBB) yang mengusulkan tentang pemberlakuan Piagam Jakarta. Tuntutan tentang pemberlakuan Piagam Jakarta dalam konstitusi juga diserukanoleh ormas-ormas Islam, sepertiyang dilakukan oleh FPI dan MMI.

Keempat,munculnya gerakan penegakan syariat Islam di Daerah, selain maraknya pembutan perda-perda syariah oleh kepala daerah, dukungan penegakan syariat Islam di daerah juga ditandai dengan maraknya simpul pejuang syariat Islam. Ada Majelis Mujahidin yang memang dibentuk untuk penegakan syariat Islam. Mereka menyusun draf revisi KUHP berdasarkan syariat Islam. Ada Komite Persiapan Syariat Islam Banten, Gerakan Penegak Syariat Islam Yogyakarta, Lembaga Pengkajian, Penegakan, dan Penerapan Syariat Islam Garut, Badan Pengkajian dan Pengembangan Syariat Islam Sukabumi, Lembaga Pengkajian dan Komite Penegakan Syariat Islam(KPSI) di Sulawesi Selatan.

\section{Positifisasi Hukum Islam sebagai Tindakan Otoritarianisme}

Uraian diatas menggambarkan bahwa perkembangan positifisasi hukum Islam sudah cukup massif baik ditingkat pusat maupun daerah, usaha untuk memformalkan hukum Islam menjadi hukum positif juga banyak suarakan oleh ormas-ormas dan partai politik Islam di Indonesia. Ketika hukum Islam telah terlembagakan menjadi hukum positif, maka masyarakat tidak memiliki pilihan lain kecuali mentaai hukum tersebut karena salah satu sifat hukum adalah memaksa. Apabila hukum tersebut dilanggar maka pihak yang melanggar mendapat sanksi dari badan-badan resmi yang berwajib di suatu negara. 
Menurut hemat penulis, mempositifkan hukum Islam sama saja dengan menutup pintu ijtihad. Suatu produk hukum Islam yang sebenarnya hanyalah hasil dari proses interpretasi dan ijtihad pihak tertentu yang sangat mungkin produk hukum Islam tersebut masuk dalam perkara khilâfiyah. Apabila suatu kasus hukum yang berstatus khilâfiyah dipaksakan baik oleh individu maupun institusi kepada masyarakat yang mungkin memiliki interpretasi yang berbeda mengenai hukum tersebut, maka pemaksaan tersebut adalah tindakan otoritarianisme yang akan berujung pada tertutupnya pintu ijtihad.

Keresahan penulis akan positifisasi hukum Islam juga dirasakan oleh Khaled Aboe El-Fadl. Beliau melihat Syariah masa kini tidak lagi tampil sebagai suatu epistemologi, proses dan metodologi pemahaman dan pencarian. Sebaliknya, ia bahkan tampil sebagai hukum-hukum yang tetap serta tertutup dari persoalan atau perbincangan lanjut tanpa adanya kemungkinan untuk pengembangan atau perubahan. Jelasnya, Abou El-Fadl kesal bahwa undang-undang Islam hadir pada masa kini sebagai aturan-aturan hukum dan bukan sebagai suatu proses fiqh. ${ }^{32}$

Peraturan-peraturan sebenarnya merupakan hasil dari suatu usaha untuk menangkap pesan suatu moralitas tertentu. Walaupun peraturan-peraturan mungkin mengambil inspirasi dari visi moral atau idea-idea normatif, namun tidak dengan sendirinya melambangkan visi moral. Abou el-Fadl menerangkan bahwa: ${ }^{33}$

Syariah as conceived by God is flawless, but as understood by humanbeings Syariah is imperfect and contingent. Jurists ought to continueto explore the ideal of Syariah and to expound their imperfect attemptsat understanding God's perfection. ... Syariah is not simply acollection of ahkam (a set of positive rules) but also a set of principles, a methodology, and a discoursive process that searches for the divineideals. As such, Syariah is a work in progress that is never complete.

Bagi Abou El-Fadl, Syariah adalah suatu proses, metodologi dan moralitas. Inti moralitas ini adalah nilai-nilai keindahan. Peraturan-peraturan atau ahkam adalah produk pemahaman manusia

32El-Fadl, Atas Nama Tuhan, 171.

33 Mohammad Muslih, "Mombongkar Logika Penafsir Agama”, Jurnal Tsaqafah, Vol. 5, No. 2, (Dhulqa'dah 1430), 442. 
terhadap Syariah, tetapi peraturan-peraturan tersebut dengan sendirinya tidak mewakili keindahan Tuhan. Artinya, peraturanperaturan tidak dapat mengartikulasi secara substantif ruh moralitas keislaman.34 Apabila ada pihak tertentu yang mempositifkan Hukum Islam yang sebenarnya hanyalah produk penafisran seseorang terhadap Syariah, maka ia telah terjatuh kepada sikap otoritarianisme.

Dalam pembacaan penulis, definisi Khaled Abou El-Fadl tentang otoritarianisme dan positifisasi hukum Islam merupakan satu bagian yang tak terpisahkan, Pertama, otoritarianisme Adalah tindakan mengunci teks ${ }^{35}$ dan mengurung kehendak tuhan atau kehendak teks, dalam sebuah penetapan makna, dan kemudian menyajikan penetapan tersebut sebagai sesuatu yang pasti, absolute dan menentukan. ${ }^{36}$ Positifisasi hukum Islam sama saja dengan tindakan mengunci dan mengurung teks. Metode penetapan hukum Islam yang didasarkan pada selektifitas teks otoritatif akan berubah menjadi teks yang otoriter setelah hukum tersrebut dipositifkan, karena dalam mendekati teks dan menyatakan suatu ketetapan makna tanpa memberi ruang bagi pamaknaan lain.

Dengan begitu, hukum positif Islam telah memposisikan dirinya sama dengan teks itu sendiri, dan bukan hanya berusaha mengkonstruksi makna teks, tetapi juga telah mengkonstruksi teks itu sendiri. Tidak sampai di situ saja, hukum Islam yang sebenarnya hanyalah tafsiran dari Syariah telah di klaim sebagai produk hukum yang paling otoritatif, dan harus diikuti oleh pihak lain. Dengan begitu, positifisasi hukum Islam telah "memperkosa" teks.

Kedua, Otoritarianisme merupakan tindakan melampaui otoritas atau kekuasaan yang dimandatkan sedemikian rupa sehingga menyelewengkan atau megambil alih kekuasaan dari pemberi mandat. ${ }^{37}$ Pada masa hidupnya, Nabi diakui sebagai suara otoritatif

34Ibid., 442.

35Teks didefinisikan sebagai sekelompok entitas yang digunakan sebagai tanda, yang dipilih, disusun, dan dimaksudkan oleh pengarang dalam konteks tertentu untuk menghantarkan beberapa makna tertentu kepada pembaca.Teks biasanya tersusun dari dari berbagai simbol, dan simbol tersebut terbentuk dari berbagai entitas. Huruf, kata, dan angka bisa menjadi sebuah tanda jika ia tersusun dari entitas yang mengandung makna. Namun dalam diskusi ini yang dimaksud dengan teks adalah al-Qur'an dan al-Hadits.

36El-Fadl, Atas Nama Tuhan, 138.

37Ibid. 
yang mewakili kehendakTuhan. Ia dipandang sebagai penerima wahyu Tuhan, sehingga secara efektif berperan sebagai otoritas dalam masyarakat Muslim paling awal. Namun setelah beliau wafat mucul pertenyaan besar, siapakah suara paling otoritatif dalam Islam ?

Dengan teori otoritas koersif dan otoritas persuasifnya Abou El-Fadl menanggapi pertanyaan diatas. Menurut El-Fadl pemegang otoritas tidak boleh bersikap koersif yaitu tindakan mengarahkan perilaku orang lain dengan cara membujuk, mengambil keuntungan, mengancam, atau menghukum, sehingga orang yang berakal sehat akan berkesimpulan bahwa untuk tujuan praktis mereka tidak punya pilihan lain kecuali harus menurutinya. Bagi El-Fadl pemegang otoritas haruslah memiliki kemampuan untuk mengarahkan keyakinan atau perilaku seseorang atas dasar kepercayaan bukan atas dasar paksaan, inilah yang dibahasakan El-Fadl sebagai otoritas persuasif. Oleh Karena itu otoritas haruslah persuasif tidak boleh koersif. Positifisasi hukum Islam adalah tindakan koersif, maka positifisais hukum Islam menganut otoritarianisme.

Dalam bingkai otoritas, tindakan positifisasi hukum Islam hanya akan terjebak dalam sikap koersif, karena orang mentaati hukum atas dasar paksaan. Sangat mungkin jika terdapat pandangan yang berbeda dari individu maupun suatu kelompok terhadap suatu kasus hukum Islam yang sudah dipositifkan, namun karena hokum pusitif memliki kekuatan memaksa, meraka tidak memilki pilihan lain keuali mentaati hokum positif tersebut dengan merelakan keprcayaan hokum Islam yang mereka yakini benar

Ketiga, Otoritarianisme merupakan tindakan dari orang-orang yang menggunakan simbolisme dari komunitas interpretasi hukum tertentu untuk mendukung argumentasi mereka. ${ }^{38}$ Positifisasi hukum Islam merupakan gagasan dari sekelompok orang yang menggunakan simbol-simbol lembaga untuk mendukung argumentasi mereka. Di Indonesia lembaga-lembaga yang menyuarakan positifisasi hukum Islam didominasi oleh ormas-ormas dan lembaga-lembaga resmi Negara.

Dari golongan ormas misalnya saja seperti Hizbut Tahrir Indonesia (HTI) yang ingin mewujudkan khilafah Islamiyah/Negara Islam yang tentu saja penyelenggaraan negaranya menggunakan

38Ibid. 
hukum positif Islam. Menurut hemat penulis, jika khilâfah Islâmiyah betul-betul terwujud, maka hal tersebut akan memunculkan penetapan hukum Islam yang bersifat pasti, absolut dan menentukan karena hukum Islam tersebut dibentuk oleh lembaga resmi (komunitas interpretasi) yang memiliki legetimasi dari Negara.

Sedangkan dari lembaga Negara tidak perlu lagi dipersoalkan masalah legitimasi, karena lembaga Negara memang memiliki kewenangan untuk mempositifkan hukum Islam, misalnya seperti Peraturan Dearah (Perda) tentang busana muslim di Sumatra barat, cianjur, tasikmalaya, perda tentang larangan larangan kegiatan pada bulan Ramadhan di Banjarmasin, Qanun tentang pidana qishas di Nangroe Aceh Darussalam dll. Padahal substansi peraturan tidaklah bersifat final dengan kata lain masih terdapat kemungkinan perbedaan penafsiran dari golongan lain. Dengan menyajikan hukum Islam sebagai sesuatu yang pasti, absolut dan menentukan hanya akan terjatuh kedalam sikap otoritarianisme.

Keempat, otoritarianisme merupakan pengabaian terhadap realitas ontologis Tuhan dan pengambilalihan kehendak Tuhan oleh wakil Tuhan sehingga wakil tersebut secara efektif kemudian mengacu kepada dirinya sendiri. ${ }^{39}$ Sebagiamana diungkapkan oleh ElFadl bahwa hukum Islam adalah produk pemahaman manusia terhadap pesan-pesan Tuhan, namun hukum Islam tersebut dengan sendirinya tidak mewakili keindahan tuhan.

Jika hukum Islam dipositifkan, tindakan tersebut sama saja dengan menutup teks-teks keislaman, hukum Islam dianggap sebagai hukum Tuhan, padahal hukum tersebut hanyalah pemahaman manusia akan hukum tuhan. Inilah dalam bahasa Amin Abdullah digambarkan sebagai "penggunaan kekuasaan tuhan" untuk membenarkan tindakan sewenang-wenang pihak tertentu dalam memahami dan menginterpretasikan teks. ${ }^{40}$

Dalam konteks Arab Saudi dan Indonsia, positifisasi hukum Islam sebagai tindakan otoritarianisme terlihat jelas. Sebagaimana sudah dijelaskan diatas, postifisasi hukum islam dai Arab Saudi

39Ibid.

${ }^{40}$ Amin Abdullah, "Pendekatan Hermeneutik dalam Fatwa-fatwa Keagamaan Proses Negosiasi Komunitas Pencari Makna Teks, Pengarang, dan Pembaca", dalam Amin Abdullah, Islamic Studies di Perguruan Tinggi Pendekatan Integratif Interkonektif, (Jogjakarta: Pustaka Pelajar, 2006), 276. 
terlihat pada lembaga fatwanya yang salah satunya adalah CRLO, lembaga tersebut berfungsi memberikan keputusan hukum atas suatu persolan yang menyangkut dengan kemaslahatan umum, baik menyangkut dengan masalah hak kewarganegaraan maupun masalah politik. Keputusan lembaga fatwa di Arab Saudi bersifat mengikat bagi seluruh warga negara Arab Saudi. Produk-produk lembaga Fatwa tersebut seperti fatwa perlarangan wanita mengunjungi makam suami, wanita mengeraskan suara dalam berdo'a, wanita mengendarai dan mengemudikan mobil sendiri, dan wanita harus didampingi pria mahramnya.

Pada hakikatnya produk fatwa tersebut hanyalah interpretasi dari ulama-ulama Arab Saudi yang masih terdapat kemungkinan benar dan salah didalamnya, selain itu masih terdapat kemungkinan adanya penafsiran dari pihak lain tentang hal-hal yang diperbolehkan dan tidak bagi seorang wanita. Ketika suatu kualitas hukum Islam yang masih dapat dipertanyakan kebenaranya kemudian hukum tersebut ditetapkan sebagai hukum yang mengikat dan memaksa, maka hukum tersebut mengandung karakter otoritarianisme.

Untuk Indonesia sendiri, Penegasan positifisasi hukum Islam dapat dijumpai pada pasal 49 UU No. 3 Tahun 2006 tentang Peradilan Agama yang menyebutkan bahwa "Pengadilan agama bertugas dan berwenang memeriksa, memutus, dan menyelesaikan perkara di tingkat pertama antara orang-orang yang beragama Islam di bidang; Perkawinan, waris, wasiat, hibah, wakaf, zakat, infaq, shadaqah , dan ekonomi syari'ah.

Untuk perkara perkawinan, kewarisan dan perwakafan, dasar hukum yang digunakan oleh Pengadilan Agama untuk memeriksan dan memutus perkara tersebut Kompilasi Hukum Islam (KHI) yang lahir dari Instruksi Presiden (Inpres) No. 1 Tahun 1991, yang kemudian disusul oleh keputusan Menteri Agama No. 154 Tahun 1991 yang memerintahkan kepada instansi pemerintah (termasuk Pengadilan Agama) dan masyarakat untuk menggunakan KHI dalam menyelesaikan perkara perkawinan, kewarisan dan perwakafan. ${ }^{41}$

Namun pada perkembanganya, terdapat pihak yang tidak sepakat dengan KHI. Pihak tersebut adalah Kelompok Kerja

41 Rachmad Budiono, Pembaruan Hukum Kewarisan Islam di Indonesia, (Jakarta, PT. Citra Aditya Bakti, 1999), 49 
Pengarusutamaan Gender Departemen Agama RI (Pokja PUG Depag) ${ }^{42}$, mereka banyak mengkritisi pasal-pasal didalam KHI yang dipandang sudah tidak relevan dengan perkembangan zaman. ${ }^{43}$ Bentuk reaksi dari ketidaksepakatan Pokja PUG Depag terhadap KHI adalah dengan membentuk tim CLD-KHI (Counter Legal Draft Kompilasi Hukum Islam). Menurut tim ini banyak pasal-pasal di dalam KHI yang tidak lagi sesuai dengan HAM, Pluralisme, Kesetaraan Gender ataupun konvensi-konvensi internasional seperti CEDAW, ICCPR, ICESCR dan lain sebaginya, sehingga tim ini mengusulkan adanya pemabaharuan KHI. Rumusan-rumusasan tentang pembaharuan KHI terdapat didalam CLD KHI. ${ }^{4}$ Namun sayangnya, tidak lebih dari satu bulan naskah CLD KHI dibekukan oleh Menteri Agama kala itu, yaitu Muhammad Maftuh Basyuni. ${ }^{45}$

Terlepas dari pro dan kontra KHI dan CLD-KHI, fenomena tersebut mendeskripsikan bahwa perbedaan pandangan dalam hukum Islam adalah hal yang wajar, namun menjadi tidak wajar ketika pandangan yang satu mebekukan pandangan yang lain dan menganggap pandanganyalah yang berhak untuk diterima oleh berbagai klangan, sebagimana fenomena KHI dan CLD-KHI, dimana KHI tetap berlaku sebagai dasar hukum bagi Pengadilan Agama sedangkan CLD-KHI dibekukan begitu saja, padahal keduanya samasama hasil ijtihad yang masih terdapat kemungkinan benar dan salahnya. Inilah yang dimaksud penulis sebagai penutupan pintu ijtihad, atau yang menurut Abou El-Fadl sebagai value judgment atas kelompok lain sebagai "tidak Islam", sesat, kafir dan seterusnya.46 Penutupan pintu ijtihad dan velue judgment adalah manifestasi dari paham otoritarianisme.

42 Pokja PUG Depag adalah suatu unit kerja yang di angkat oleh Menteri Agama RI untuk terselenggaranya perencanaan, penyusunan, pelaksanaan, pemantauan, dan evaluasi atas kebijakan dan program pembangunan nasional yang berprespektif gender dalam rangka mewujudkan kesetaraan dan keadilan gender dalam berkeluarga, bermasyarakat, berbangsa dan bernegara di lingkungan Departemen Agama.

43 Marzuki Wahid, Fiqih Indonesia: Kompilasi Hukum Islam dan Counter Legal Draft Kompilasi Hukum Islam dalam Bingkai Politik Hukum Islam (Bandung: Marja, 2014), 365.

44Ibid., 369-371.

45 Ibid., 201.

46 Sirry, Islam, Teks Terbuka, 30. 
Uraian diatas menjelaskan bahwa positifisasi hukum Islam kedalam hukum nasional hanya akan terjatuh kedalam sikap otoritarianisme, baik melalaui mahkamah syariah dan lembaga fatwa seperti di Arab Saudi, ataupun melalui lembaga legislatif, eksekutif ataupun yudikatif seperti di Indonesia. Multi tafsir terhadap teks (alQur'an dan al-Hadits) adalah fitrah, tentu bukanlah tidakan yang bijaksana jika ada pihak yang mempositifkan hukum Islam hanya dari salah satu produk penafsiran seseorang diantara beragamnya produk penafsiran lain akan hukum Islam tersebut.

Agama Islam yang dipahami plural oleh para pemeluknya, tidak tepat jika dipahami dengan logika positifstik yang cenderung kaku dan mengikat. Dalam hal ini penulis sependapat dengan Nurcholis Madjid yang menempatkan Agama Islam pada tingkat yang lebih abstrak sebagai nilai-nilai etis, yang berfungsi memberikan arah serta orientasi kepada umatnya, Islam tidak dipahami sebagai agama bersifat legal-formalistik, yang melahirkan formalisme susunan hukum dan struktur politik kenegaraan. Islam harus melahirkan jiwa demokratis yang menghargai prinsip-prinsip prulalisme yang selaras dengan arus modernisasi. ${ }^{47}$

Pembaharuan Islam yang digelorakan Nurcholis Madjid, yang lebih banyak mengutamakan pendekataan inklusivitas, dalam masyarakat Indonesia yang majemuk, ternyata dapat melestarikan komunikasi dengan golongan lain khususnya dengan pemerintah. Menurut Rusli Karim, ${ }^{48}$ gagasan modernisme Islam Nurcholis Madjid, telah banyak membantu melicinkan interaksi umat Islam di Indonesia dalam bingkai NKRI, serta mengiliminasi tuduhan umat Islam tertutup, yang hanya bertujuan mendirikan negara Islam. Berbeda dengn positifisasi hukum Islam yang hanya akan membawa nuansa otoritarian dalam berbangsa dan bernegara khususnya di Indonesia yang masyarakatnya majemuk.

Hukum Islam sepatutnya diposisikan sebagai "kultur hukum" yang jauh dari nalar positifistik. Kultur hukum diartikan oleh Prof. Dr. Ahmad Ali, sebagai ide-ide, sikap-sikap, kepercayaan-

\footnotetext{
47 Siti Nadroh, Wacana Keagamaan dan Politik Nurcholis Madjid (Jakarta: PT. Raja Grafindo Persada, 1999), 180.

${ }^{48}$ Rusli Karim, HMI MPO dalam Kemelut Politik di Indonesia (Bandung: Mizan, 1997), 115.
} 
kepercayaan, harapan-harapan dan opini seseorang akan hukum, ${ }^{49}$ sehingga mampu menangkap nilai-nilai etis yang ada di dalam masyarakat. Istilah Kultur hukum menjadi tepat untuk hukum Islam, mengingat terdapat varian pemahaman yang berbeda dari masyarakat muslim akan ide, sikap, kepercayaan, harapan dan opini terhadap hukum Islam.

\section{Penutup}

Usaha-usaha memosisikan hukum Islam sebagai hukum positif memiliki konsekwensi yang besar dalam bingkai berbangsa dan bernegara bagi masyarakat muslim pada khususnya dan masyarakat Indonesia secara umum. Positifisasi hukum Islam mengakibatkan masyarakat Indonesia tidak memiliki pilihan lain kecuali melaksankan hukum Islam yang telah tetapkan menjadi hukum positif di Indonesia, padahal hukum tersebut hanyalah hasil interpretasi manusia belaka yang bisa jadi hasil interpretasi tersebut termasuk dalam perkara khilâfiyah. Apabila suatu kasus hukum yang berstatus khilâfiyah dipaksakan baik oleh individu maupun institusi kepada masyarakat yang mungkin memiliki interpretasi yang berbeda mengenai hukum tersebut, maka pemaksaan tersebut adalah tindakan otoritarianisme.

Positifisasi hukum Islam tercermin dari empat definisi Abou Khaled El-Fadl tentang otoritarianisme; Pertama, Positifisasi hukum Islam sama saja dengan tindakan mengunci dan mengurung teks. Metode penetapan hukum Islam yang didasarkan pada selektifitas teks otoritatif akan berubah menjadi teks yang otoriter setelah hukum tersrebut dipositifkan, karena dalam mendekati teks dan menyatakan suatu ketetapan makna tanpa memberi ruang bagi pamaknaan lain. Kedua, Positifisasi hokum Islam hanya akan menciptakan pemegang otoritas yang bersikap koersif, yaitu pemegang otoritas yang

49 Ahmad Ali, Reaktualisasi The Living Law dalam Masyarakat Sulawesi Selatan. Makalah disampaikan dalam Seminar tentang Revitalisasi dan Reinterpretasi Nilai-nilai Hukum Tidak Tertulis Dalam Pembentukan dan Penemuan Hulrum, diselenggarakan oleh BPHN Departemen Hukum dan HAM RI bekerjasama dengan Fakultas Hukum Universitas Hasanuddin dan Kanwil Departemen Hukum dan HAM RI Provinsi Sulawesi Selatan, tanggal 28-30 September 2005 di Makassar. 
mengarahkan perilaku orang lain dengan cara memaksa. Ketiga, Positifisasi hukum Islam merupakan gagasan dari sekelompok orang yang menggunakan simbol-simbol lembaga untuk mendukung argumentasi mereka. Di Indonesia, lembaga-lembaga yang menyuarakan positifisasi hukum Islam didominasi oleh ormas-ormas dan lembaga-lembaga resmi Negara. Keempat, Positivsasi hukum Islam sama saja menutup teks-teks keislaman karena hukum Islam dianggap sebagai hukum tuhan padahal hukum tersebut hanyalah pemahaman manusia akan hukum tuhan.

Dengan demikian, tidaklah tepat jika hukum Islam dimaknai dengan logika positivistik. Istilah Kultur hukum menjadi tepat untuk hukum Islam, mengingat terdapat varian pemahaman yang berbeda dari masyarakat muslim akan ide, sikap, kepercayaan, harapan dan opini terhadap hukum Islam.

\section{Daftar Pustaka}

Abdillah, Masykuri, et.al. Formalisasi Syari'at Islam di Indonesia: Sebuah Pergulatan Yang Tak Pernah Tuntas. Jakarta: Renaisan. 2005.

Abdullah, Amin. Islamic Studies di Perguruan Tinggi Pendekatan Integratif Interkonektif. Jogjakarta: Pustaka Pelajar, 2006.

------.. "Pendekatan Hermeneutik dalam Studi Fatwa-fatwa Keagamaan", dalam kata pengantar Khaled Abou El-Fadl, Atas Nama Tuhan, Dari Fikih Otoriter ke Fikih Otoritatif. Jakarta: Serambi, 2004.

Al-Munawar, Said Agil Husin. “Islam dalam Konteks KeIndonesiaan: Beberapa Soal yang Segera Dirumuskan", dalam Formalisasi Syariat Islam di Indonesia: Sebuah Pergulatan yang Tak Pernah Tuntas, eds. Maykuri Abdillah, et.al.. Jakarta: Renaisan, 2005.

Ali, Achmad. Menguak Teori Hukum (Legal Theory) dan Teori Peradilan (Judicialprudence) Termasuk Interpretasi UndangUndang/Legisprudence. Jakarta: Kencana, 2009.

Budiono, Rachmad. Pembaruan Hukum Kewarisan Islam di Indonesia. Jakarta: PT. Citra Aditya Bakti, 1999.

Burhanuddin, Syari'at Islam Pandangan Muslim Liberal. Jakarta: The Asia Fondation, 2003.

--------, Reaktualisasi The Living Law dalam Masyarakat Sulawesi Selatan. Makassar: Makalah Seminar Hukum, 2005. 
El-Fadl, Khaled Abou. Atas Nama Tuha, Dari Fikih Otoriter ke Fikih Otoritatif. terj. R. Cecep. Jakarta: Serambi, 2004.

--------, Melawan Tantara Tuhan: Yang Berwenang dan Sewenang-wenang dalam Islam, terj. Kurniawan Abdullah. Jakarta: Serambi, 2003.

Gurvitch, Georges. Sosiologi Hukum, terj. Sumantri Mertodipuro dan Moh.Radjab. Jakarta: Penerbit Bhratara, 1988.

Jazuni. Legislasi Hukum Islam di Indonesia. Bandung: PT.Citra Adtya Bakti, 2005.

Kansil, C.ST. Pengantar Ilmu Hukum dan Tata Hukum Indonesia. Jakarta: Balai Pustaka, 2002.

Karim, Rusli. HMI MPO dalam Kemelut Politik di Indonesia. Bandung: Mizan, 1997.

Munawwir, AW. Kamus al-Munawwir Arab-Indonesia Terlengkap, Surabaya: Penerbit Pustaka Progresif.

Muslih, Mohammad. "Mombongkar Logika Penafsir Agama", Jurnal Tsaqafah. Vol. 5, No. 2 (Dhulqa' dah 1430).

Nadroh, Siti. Wacana Keagamaan dan Politik Nurcholis Madjid. Jakarta: PT. Raja Grafindo Persada, 1999.

Putro, Widodo Dwi. Kritik Terhadap Paradigma Positivisme Hukum. Yogyakarta: Genta Publising, 2011.

Setiawan, Zudi. "Dinamika Pergulatan Politik dan Pemikiran Formaslisasi Syariah pada Era Reformasi", Jurnal Spektrum Vol. 5, No. 2 (Juni 2008).

Sirry, Mun'im A. "Islam, Teks Terbuka dan Pluralisme”, Jurnal Perspektif Progresif, Vol. 1, No. 1 (Juli-Agustus, 2005).

Sjadzali, Munawir. Islam dan Tata Negara (Ajaran, Sejarah dan Pemikiran. Jakarta: UI Press, 1993.

Tanya. Bernard L. Dkk. Teori Hukum: Strategi tertib Manusia Lintas Ruang dan Generasi. Yogyakarta: Genta Publishing, 2010.

Wahid, Marzuki. Fiqih Indonesia: Kompilasi Hukum Islam dan Counter Legal Draft Kompilasi Hukum Islam dalam Bingkai Politik Hukum Islam. Bandung: Marja, 2014.

Wikipedia, https://en.wikipedia.org/wiki/Khaled_Abou_El_Fadl. Diakses pada tanggal 14 Juli 2015. 